\title{
Abiotic Reactivity of De Novo Designed Artificial Copper Peptides (ArCuPs): The Case of C-H Activation
}

\author{
Divyansh Prakash, Suchitra Mitra, Morgan Murphy, Saumen Chakraborty* \\ Department of Chemistry and Biochemistry, University of Mississippi, University, MS 38677, USA
}

\begin{abstract}
We report a series of de novo designed Artificial $\mathrm{Cu}$ Peptides (ArCuPs) that oxidize and peroxygenate C-H bonds of model abiotic substrates via electrochemically generated Cu-oxygen species using $\mathrm{H}_{2} \mathrm{O}_{2}$ as the terminal oxidant, akin to native $\mathrm{Cu}$ enzymes. Detailed assessment of kinetic parameters established the catalytic nature of the ArCuPs. Selective alteration of outer sphere steric at the $\boldsymbol{d}$ layers above and below the $\mathrm{Cu}$ site allows facilitated access of substrates, where a more pronounced effect on catalysis is observed when space is created at the $\boldsymbol{d}$ layer below the $\mathrm{Cu}$ site via Ile to Ala mutation producing a $k_{\text {cat }}$ of $6.2 \mathrm{~s}^{-1}$, TON max of 14800 and catalytic proficiency $\left(k_{\text {cat }} / \mathrm{K}_{\mathrm{M}} / k_{\text {uncat }}\right)$ of $2520 \mathrm{M}^{-1}$ for the oxidation of benzyl alcohol. Independent spectroscopic studies revealed that the rate of formation of the $\mathrm{Cu}$-oxygen species and the spectroscopic feature of the most active variant is distinct compared to the other ArCuPs. Systematic alteration of outer sphere hydrophobicity led to a correlated tuning of the T2 Cu site redox potentials by $\sim 80 \mathrm{mV}$. The enhanced activity of the $\mathrm{ArCuP}$ variant is attributed to a combination of steric effect that allows easy access of substrates, the nature of $\mathrm{Cu}$-oxygen species, and stability of this construct compared to others, where Ile to Ala mutation unexpectedly leads to a higher thermostability which is further augmented by $\mathrm{Cu}$ binding.
\end{abstract}

\section{INTRODUCTION}

Copper $(\mathrm{Cu})$ containing proteins carry out diverse functions in biology starting from electron transfer (ET) to substrate activation, thanks to the abundance of $\mathrm{Cu}$ in the geosphere, its accessible redox potentials $\left(\mathrm{E}^{0}\right)$, and favorable electronic properties. ${ }^{[1]}$ The protein scaffold controls the coordination number, ligand environment, and geometry, which further finetunes the physical and reactivity properties of $\mathrm{Cu}$. While the type I (T1) $\mathrm{Cu}$ proteins are exclusively involved in ET, the T2 $\mathrm{Cu}$ proteins participate in both ET and substrate activation. For example, in non-coupled binuclear enzyme peptidyl glycine $\alpha-$ hydroxylating monooxygenase (PHM), the substrate activation occurs at a $\mathrm{T} 2 \mathrm{Cu}_{\mathrm{M}}$ center featuring $\mathrm{Cu}(\mathrm{His})_{2}$ Met coordination, while the second $\mathrm{T} 2 \mathrm{Cu}_{\mathrm{H}}$ site $\sim 11 \AA$ away with a $\mathrm{Cu}(\mathrm{His})_{3}$ coordination participates in ET (Fig. 1A). PHM catalyzes the activation of $\mathrm{C}-\mathrm{H}$ bonds (BDE $\sim 89 \mathrm{kcal} / \mathrm{mol}$ ), in some cases showing regioselectivity for secondary $\mathrm{C}-\mathrm{H}$ bonds over primary $\mathrm{C}-\mathrm{H}$ bonds. ${ }^{[1 \mathrm{c}]}$ Galactose oxidase (GO) is a monocopper enzyme that oxidizes primary alcohols to aldehydes using molecular $\mathrm{O}_{2}$. Lytic polysaccharide monooxygenases (LPMOs) are mononuclear T2 $\mathrm{Cu}$ enzymes (Fig. 1B) that degrade recalcitrant polysaccharides into simpler precursors for biofuels and other useful products. ${ }^{[2]}$ Discovery of LPMOs are attractive from both fundamental science and industrial perspectives to degrade cellulosic biomass into useful chemicals using both $\mathrm{O}_{2}$ and $\mathrm{H}_{2} \mathrm{O}_{2}$ as terminal oxidants. The reaction rates are greatly accelerated when $\mathrm{H}_{2} \mathrm{O}_{2}$ is used instead of $\mathrm{O}_{2}$ under reducing conditions, leading to the implication that these enzymes are peroxygenases instead of monooxygenases. ${ }^{[3]}$ In addition to the active site, the local environment and outer coordination sphere interactions play crucial roles in tweaking the activity of $\mathrm{Cu}$ enzymes. ${ }^{[1 \mathrm{c}]}$ For example, hemocyanin $(\mathrm{Hc})$ and tyrosinase (Ty) are structurally similar, both have binuclear $\mathrm{Cu}---\mathrm{Cu}$ active sites and produce similar $\mathrm{Cu}-\mathrm{O}_{2}$ intermediates. Yet, Ty shows mono and diphenolase activity, while Hc does not. This differential reactivity has been attributed to differences in substrate access between these two proteins. ${ }^{[1 \mathrm{c}, 4]}$ From enzymatic and modeling studies superoxo $\left(\mathrm{Cu}^{\mathrm{II}}-\mathrm{O}_{2}{ }^{--}\right)$, hydroperoxo $\left(\mathrm{Cu}^{\mathrm{II}}-\mathrm{OOH}\right)$, and high-valent oxo $(\mathrm{Cu} \equiv \mathrm{O})$ or oxyl $\left(\mathrm{Cu}^{\mathrm{II}}-\mathrm{O}_{2}{ }^{\bullet}\right)$ type intermediates have been proposed to form as the reactive species in $\mathrm{Cu}$ enzymes. ${ }^{[1 \mathrm{c}, 5]}$

Design of artificial metalloenzymes (ArMs) as functional analogues of native enzymes is an attractive approach for the development of efficient and sustainable biocatalysts. ${ }^{[6]} \mathrm{We}$ have been employing de novo protein design approach to create artificial $\mathrm{Cu}$ proteins (ArCuPs) within self-assembling scaffolds. ${ }^{[7]}$ A particular focus is to expand the functional diversity of these constructs into previously unexplored areas, ${ }^{[8]}$ including energy relevant catalysis. ${ }^{[7,9]}$ As complex enzyme structures are made up of peptides, which are subsequently synthesized from amino acid building blocks, de novo metalloenzyme design approach provides a handle to explore how primary sequence determines the folding and function of complex metalloenzymes. ${ }^{[10]}$ In addition, the
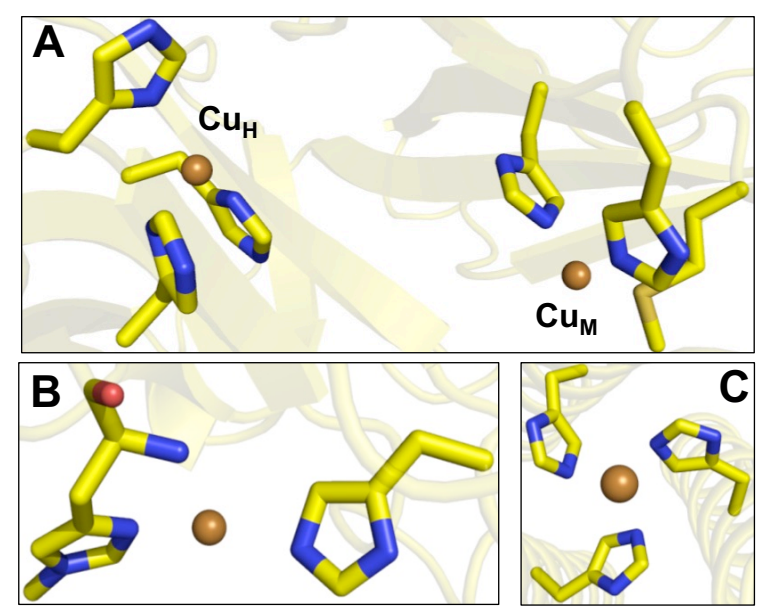

Figure 1. Active site structures of A) PHM (pdb: 3MIH), B) LPMO (pdb: 2YET), and C) 3SCC (pdb: 7L33).

simpler de novo proteins help elucidate the catalytic and mechanistic underpinning of complex native enzymes. Predefined rules to create specific oligomeric assemblies of de novo design ${ }^{[11]}$ allows an unprecedented control over the 
coordination number, protein stability, and non-covalent interactions to fine tune the physical and catalytic properties of these ArMs.

We have recently reported the design, structural characterization and $\mathrm{H}_{2} \mathrm{O}_{2}$ activation properties by a trimeric $\mathrm{ArCuP}$ (3SCC) featuring a $\mathrm{Cu}(\mathrm{His})_{3}$ active site (Fig. 1C). ${ }^{[7]}$ Herein, we expand the repertoire of reactivity of 3SCC into activation of $\mathrm{C}-\mathrm{H}$ bonds of model substrates with varying $\mathrm{CH}_{\text {BDE }}$ using $\mathrm{Cu}$-oxygen species generated with $\mathrm{H}_{2} \mathrm{O}_{2}$ under reducing conditions as reactive intermediates. Outer sphere steric are systematically altered to control substrate access, influence the rates of $\mathrm{Cu}$-oxygen species formation, tune the $\mathrm{E}^{0} \mathrm{~s}$, and to alter the stability of the ArCuPs. We find that local packing effects dictate how removal of steric bulk in one side of the $\mathrm{Cu}$ site preferentially enhances catalysis $\left(k_{c a t}\right)$ and favors substrate binding $\left(\mathrm{K}_{\mathrm{M}}\right)$, ultimately tuning the catalytic proficiency $\left(k_{\text {cat }} / \mathrm{K}_{\mathrm{M}}\right) / k_{\text {uncat }}$. A delicate relationship between substrate accessibility, rates, $\mathrm{E}^{0} \mathrm{~s}$, and peptide stability is found, which ultimately control the reactivity pattern.

\section{RESULTS AND DISCUSSION}

\section{Catalysis}

i. Electrocatalysis: The catalytic properties of ArCuPs were studied using protein film voltammetry (PFV) using $\mathrm{H}_{2} \mathrm{O}_{2}$ as the terminal oxidant. Analogous to heme systems employing $\mathrm{O}_{2},{ }^{[12]}$ the premise is centered on the hypothesis that the electrochemically generated reactive $\mathrm{Cu}$-oxygen intermediates are potent oxidants to activate $\mathrm{C}-\mathrm{H}$ bonds. Substrates $\mathbf{1 - 5}$ with varying $\mathrm{C}-\mathrm{H}_{\mathrm{BDE}}$ of $85-98 \mathrm{kcal} / \mathrm{mol}$ are chosen (Scheme 1) in this study. The catalytic response of 3SCC adsorbed as films $(0.125 \mathrm{mM})$ on PGE is assessed by following linear sweep voltammograms (LSVs) with substrates in the presence of 100fold $\mathrm{H}_{2} \mathrm{O}_{2}$. Previously we have shown that the saturating concentration for $\mathrm{H}_{2} \mathrm{O}_{2}$ is $\sim 12.5 \mathrm{mM},{ }^{[7]}$ which is why all experiments are performed with $12.5 \mathrm{mM} \mathrm{H}_{2} \mathrm{O}_{2}$. In the absence of substrates, reduction of $\mathrm{H}_{2} \mathrm{O}_{2}$ occurs (Fig. 2A dark yellow) ${ }^{[7]}$ In the presence of substrates 1-5 (1-black; 2-blue; 3red; 4-olive; 5-orange), large catalytic currents with onset potentials ( $\mathrm{E}_{\text {onset }}$ ) of $\sim 50 \mathrm{mV}$ vs $\mathrm{Ag} / \mathrm{AgCl}$ are observed (Fig. 2A). The blank electrode does not show any appreciable current with $\mathrm{H}_{2} \mathrm{O}_{2}$ (gray), in presence of substrate (1-violet), and in the presence of both $\mathrm{H}_{2} \mathrm{O}_{2}$ and $\mathbf{1}$ (dark gray). Further control experiments with $3 \mathrm{SCC}$ and the substrate, but in the absence of $\mathrm{H}_{2} \mathrm{O}_{2}$ did not show catalytic response (navy). This result suggests that $\mathrm{H}_{2} \mathrm{O}_{2}$ is necessary as the terminal oxidant and that the $\mathrm{Cu}$-oxygen intermediate is the active species, which is why catalytic currents of ArCuPs are observed only in the presence of both $\mathrm{H}_{2} \mathrm{O}_{2}$ and substrate(s). In the absence of $\mathrm{H}_{2} \mathrm{O}_{2}$, the $\mathrm{Cu}-\mathrm{OOH}$ intermediate is not formed and therefore no catalytic response is observed. To establish that the observed

Table 1. Peptides and their sequences used in this study.
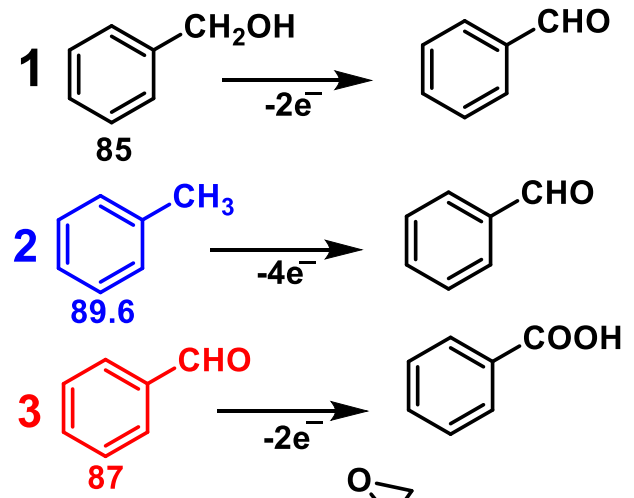<smiles>CC(C)(C)c1cccc(C=O)c1</smiles><smiles></smiles>

Scheme 1. Substrates used in this study and the corresponding products formed.

activity is attributable to the $\mathrm{Cu}(\mathrm{His})_{3}$ active site and not from adventitiously bound $\mathrm{Cu}$, the active site His residues were replaced with Ile. The 3SCC-His variant (Table 1 shows the sequence), owing to its inability to bind $\mathrm{Cu}$ and therefore the lack of formation of the reactive species, showed negligible current as compared to 3SCC (Fig. 2A wine) in the presence of $\mathrm{H}_{2} \mathrm{O}_{2}$ and $\mathbf{1}$. This result highlights the importance of the active site to enable catalysis.

ii. Product analysis: In order to detect and quantify the products of electrochemical oxidation, controlled potential electrolysis (CPE) experiments were performed at $-950 \mathrm{mV}$ vs $\mathrm{Ag} / \mathrm{AgCl}$ for $1 \mathrm{~h}$ to generate the oxidation products. At the end of electrolysis, the products were extracted in dichloromethane and detected using gas chromatography (GC). These analyses led to the identification of the products as benzaldehyde from $\mathbf{1}$ and $\mathbf{2}$, benzoic acid from $\mathbf{3}$, styrene oxide and benzaldehyde (in 1:2.5 ratio) from 4. The amount of charge passed during electrolysis (Fig. 2B, Fig. S1-5) was significantly large, 6fold, with $3 \mathrm{SCC} / \mathrm{H}_{2} \mathrm{O}_{2} /$ substrates compared to the control experiments with $3 \mathrm{SCC}-\mathrm{His} / \mathrm{H}_{2} \mathrm{O}_{2} /$ substrates. No product was observed for either the blank electrode (without 3SCC) or with $3 \mathrm{SCC}-\mathrm{His} / \mathrm{H}_{2} \mathrm{O}_{2} /$ substrates. To probe regioselectivity, ethylbenzene 5 was employed.

\begin{tabular}{cllll}
\hline Peptide & \multicolumn{3}{c}{ Sequence } \\
\hline 3SCC & Ac GIAAIKQE & HAAIKQE & IAAIKQE & IAAIKWEG CONH \\
3SCC-His & Ac GIAAIKQE & IAAIKQE & IAAIKQE & IAAIKWEG CONH \\
I5A-3SCC & Ac GIAAAKQE & HAAIKQE & IAAIKQE & IAAIKWEG CONH 2 \\
I12A-3SCC & Ac GIAAIKQE & HAAAKQE & IAAIKQE & IAAIKWEG CONH \\
I5AI12A-3SCC & Ac GIAAAKQE & HAAAKQE & IAAIKQE & IAAIKWEG CONH \\
\hline
\end{tabular}


The oxidation products of 5 are acetophenone $\left(2^{\circ} \mathrm{C}-\mathrm{H}\right.$ bond $)$ and phenylacetaldehyde $\left(1^{\circ} \mathrm{C}-\mathrm{H}\right.$ bond) produced at a ratio of $9: 1$. This result suggests that the $\mathrm{Cu}$-oxygen species selectively oxidizes benzylic $\mathrm{C}-\mathrm{H}$ bonds $\left(\mathrm{C}-\mathrm{H}_{\mathrm{BDE}}=85 \mathrm{kcal} / \mathrm{mol}\right)$ of 5 over primary $\mathrm{C}-\mathrm{H}$ bonds $\left(\mathrm{C}-\mathrm{H}_{\mathrm{BDE}}=98 \mathrm{kcal} / \mathrm{mol}\right)$, similar to what is observed in PHM as well. ${ }^{[\mathrm{c}]}$ Together, these results demonstrate that the 3SCC ArCuP supports multi-electron oxidation and peroxygenation processes, and that the designed $\mathrm{Cu}(\mathrm{His})_{3}$ site is where the substrate activation occurs.

iii. Assessment of catalytic activity: The catalytic efficiency $\left(k_{\text {cat }} / \mathrm{K}_{\mathrm{M}}\right)$ is determined in the $\mathrm{pH}$ range of 5.5-9.5 (Fig. S6-7), which shows that the maximum activity occurs at $\mathrm{pH} 6.5$ (Fig. 2C). The relevant catalytic parameters are shown in Table 2. The highest $k_{\text {cat }}$ of $\sim 3.5 \mathrm{~s}^{-1}$ and turnover number (TON) of $\sim 8.2 \times 10^{3}$ for $3 \mathrm{SCC}$ was obtained with 1 and 4 . The $\mathrm{K}_{\mathrm{M}}$ was in
$\mathrm{mM}$ range for all the substrates, with the lowest $\mathrm{K}_{\mathrm{M}}$ of $22.7 \mathrm{mM}$ for 5. The highest catalytic proficiency $\mathrm{I} / \mathrm{K}_{\mathrm{TS}}\left(k_{\text {cat }} / \mathrm{K}_{\mathrm{M}}\right) / k_{\text {uncat }}$ $\left(K_{\mathrm{TS}}\right.$ is the apparent transition-state binding affinity; ${ }^{[13]} k_{\text {uncat }}$ is obtained with 3 SCC-His variant) was observed for $\mathbf{3}$. To obtain mechanistic insight and to determine the rate determining step (RDS), a Hammett analysis was performed. The activity of $p$ substituted derivatives of $\mathbf{1}$ varied with electron withdrawing substituents (-OMe, - Me, $-\mathrm{Cl},-\mathrm{NO}_{2}$ ) producing a linear correlation with a negative slope $(\rho)$ of -0.5 (Fig. 2D), suggesting that a positive charge is created in the ratedetermining step (RDS). A similar $\rho$ value has been observed in $\mathrm{GO}^{[14]}$ and a synthetic complex ${ }^{[5 \mathrm{~h}]}$ reported by Itoh and coworkers. A primary kinetic isotope effect $\left(\mathrm{KIE}=k_{H} / k_{D}\right)$ of 2.8 was obtained for $\mathrm{PhCD}_{2} \mathrm{OH}$, which indicate that $\mathrm{H}$-atom transfer (HAT) is the RDS.
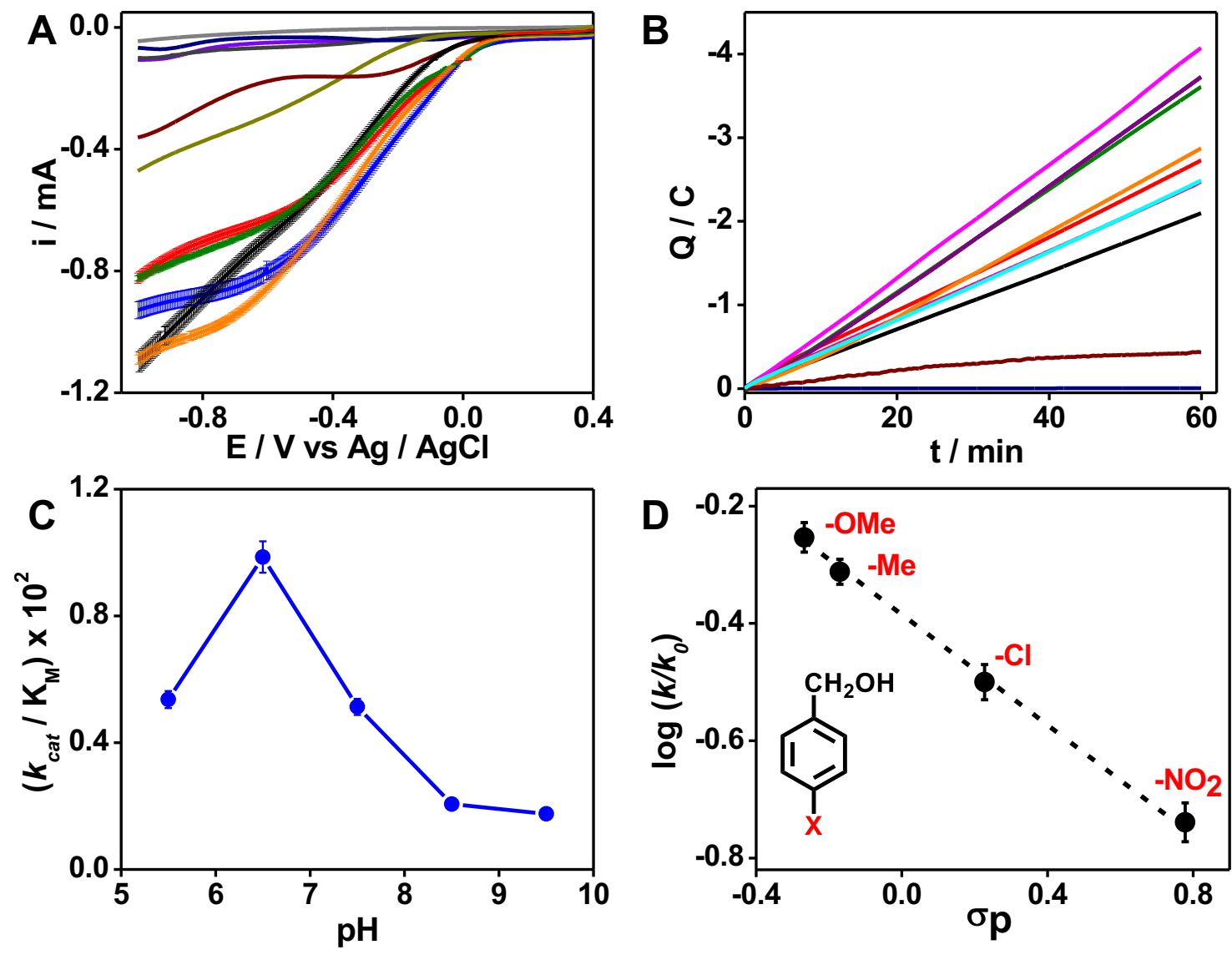

Figure 2. A) LSVs of blank SWNT/PBSE on GCE in the presence of $\mathrm{H}_{2} \mathrm{O}_{2}$ (gray); in the presence of $\mathbf{1}$ but without $\mathrm{H}_{2} \mathrm{O}_{2}$ (violet); in the presence of both $\mathrm{H}_{2} \mathrm{O}_{2}$ and $\mathbf{1}$ (dark gray). The corresponding LSVs for $3 \mathrm{SCC}+\mathbf{1}$ (navy); $3 \mathrm{SCC}+\mathrm{H}_{2} \mathrm{O}_{2}$ (dark yellow; $\mathrm{H}_{2} \mathrm{O}_{2}$ reduction); $3 \mathrm{SCC}+\mathrm{H}_{2} \mathrm{O}_{2}+\mathbf{1 - 5}:\left(\mathbf{1}=\right.$ black, $\mathbf{2}=$ red, $\mathbf{3}=$ blue, $\mathbf{4}=$ olive, $\mathbf{5}=$ orange); $3 \mathrm{SCC}-\mathrm{His}+\mathrm{H}_{2} \mathrm{O}_{2}+\mathbf{1}$ (wine). In all the experiments, $[3 \mathrm{SCC}]=0.125 \mathrm{mM},\left[\mathrm{H}_{2} \mathrm{O}_{2}\right]=12.5 \mathrm{mM}$, and [1-5] $=125 \mathrm{mM} .10 \mu \mathrm{L}$ of SWNT/PBSE/peptide samples were dropped on GCE and the film was dried under a gentle flow of $\mathrm{N}_{2}$. The LSVs were recorded in $\mathrm{N}_{2}$ saturated $80 \mathrm{mM}$ mixed buffer at $\mathrm{pH} 6.5$ with $v=100 \mathrm{mVs}^{-1}$. The shaded region represents error bars from three separate experiments of fresh protein films at each condition. B) Q vs t traces from $1 \mathrm{~h} \mathrm{CPE}$ experiments performed at $-950 \mathrm{mV}$ vs Ag/AgCl. Blank electrode SWNT/PBSE + $\mathrm{H}_{2} \mathrm{O}_{2}+\mathbf{1}$ (navy); 3SCC $+\mathrm{H}_{2} \mathrm{O}_{2}+\mathbf{1}$ (black); I5A-3SCC $+\mathrm{H}_{2} \mathrm{O}_{2}+\mathbf{1}$ (red); I12A-3SCC $+\mathrm{H}_{2} \mathrm{O}_{2}+\mathbf{1}$ (blue); and I5AI12A-3SCC + $\mathrm{H}_{2} \mathrm{O}_{2}+\mathbf{1}$ (olive). Traces are also shown for I12A-3SCC $+\mathrm{H}_{2} \mathrm{O}_{2}+\mathbf{1 - 5}$ where $\mathbf{1}=$ purple, $\mathbf{2}=$ cyan, $\mathbf{3}=$ magenta, $\mathbf{4}=$ pink, and $\mathbf{5}$ $=$ orange; and the control peptide $3 \mathrm{SCC}-\mathrm{His}+\mathrm{H}_{2} \mathrm{O}_{2}+\mathbf{1}$ (purple). C) Plot of $k_{c a t} / \mathrm{K}_{\mathrm{M}} \mathrm{vs} \mathrm{pH}$ for the electrocatalytic oxidation of 1 to benzaldehyde. D) Hammett analysis of p-substituted derivatives of $\mathbf{1}$ in presence of $\mathrm{H}_{2} \mathrm{O}_{2}$ and $3 \mathrm{SCC}$. All experiments were performed in $\mathrm{N}_{2}$-saturated buffers. 
Table 2. Catalytic parameters of the ArCuPs for 1-5 at pH 6.5 extracted from data in Fig. 2, Fig. S1-7.

\begin{tabular}{|c|c|c|c|c|c|c|}
\hline ArCuP & Parameters & 1 & 2 & 3 & 4 & 5 \\
\hline \multirow[t]{4}{*}{$3 \mathrm{SCC}$} & $k_{\text {cat }} / \mathbf{s}^{-1}$ & 3.5 & 2.3 & 2.3 & 3.4 & 1.5 \\
\hline & $\mathbf{K}_{\mathbf{M}} / \mathbf{m M}$ & 35.7 & 23.3 & 27.9 & 42.1 & 19.8 \\
\hline & $1 / k_{T S} \times 10^{3} / M^{-1}$ & 1.4 & 0.9 & 1.3 & 0.5 & 0.4 \\
\hline & $\mathbf{T O N}_{\max } \times 10^{3}$ & 8.2 & 5.8 & 5.6 & 8.1 & 5.5 \\
\hline \multirow[t]{4}{*}{ 15A-3SCC } & $k_{\text {cat }} / \mathbf{s}^{-1}$ & 4.5 & 2.7 & 2.4 & 3.7 & 1.9 \\
\hline & $\mathbf{K}_{\mathbf{M}} / \mathbf{m} \mathbf{M}$ & 32.3 & 25.8 & 27.1 & 40.8 & 22.7 \\
\hline & $1 / k_{T S} \times 10^{3} / \mathbf{M}^{-1}$ & 1.9 & 1.0 & 1.4 & 0.6 & 0.5 \\
\hline & $\mathbf{T O N}_{\max } \times 10^{3}$ & 10.7 & 6.6 & 5.9 & 9 & 6.9 \\
\hline \multirow[t]{4}{*}{ I12A-3SCC } & $\boldsymbol{k}_{\text {cat }} / \mathbf{s}^{-1}$ & 6.2 & 3.3 & 4.1 & 4.1 & 2.4 \\
\hline & $\mathbf{K}_{\mathbf{M}} / \mathbf{m} \mathbf{M}$ & 34.7 & 20 & 18.4 & 31.8 & 24 \\
\hline & $1 / k_{T S} \times 10^{3} / \mathbf{M}^{-1}$ & 2.5 & 1.6 & 3.7 & 0.8 & 0.6 \\
\hline & $\mathbf{T O N}_{\max } \times 10^{3}$ & 14.8 & 7.9 & 9.9 & 9.9 & 8.6 \\
\hline \multirow[t]{4}{*}{ I5AI12A-3SCC } & $k_{\text {cat }} / \mathbf{s}^{-1}$ & 6 & 3 & 4 & 3.6 & 2.1 \\
\hline & $\mathbf{K}_{\mathbf{M}} / \mathbf{m M}$ & 39.7 & 36 & 40.8 & 66.6 & 26.9 \\
\hline & $1 / k_{T S} \times 10^{3} / M^{-1}$ & 2.1 & 0.8 & 1.6 & 0.3 & 0.4 \\
\hline & $\mathbf{T O N}_{\max } \times 10^{3}$ & 14.3 & 7.4 & 9.6 & 8.7 & 7.8 \\
\hline 3SCC-His & $k_{\text {uncat }} / \mathbf{s}^{-1}$ & 0.07 & 0.10 & 0.06 & 0.15 & 0.16 \\
\hline
\end{tabular}

2. Selective alteration of outer sphere steric enhances the rates, reactivity, and $\mathbf{E}^{\mathbf{0}^{\prime}}$

i. Design considerations: Inspection of the 3SCC structure reveals that bulky hydrophobic residues pack above (Fig. 3A) and below (Fig. 3B) the $\mathrm{Cu}$ site, which can restrict substrate

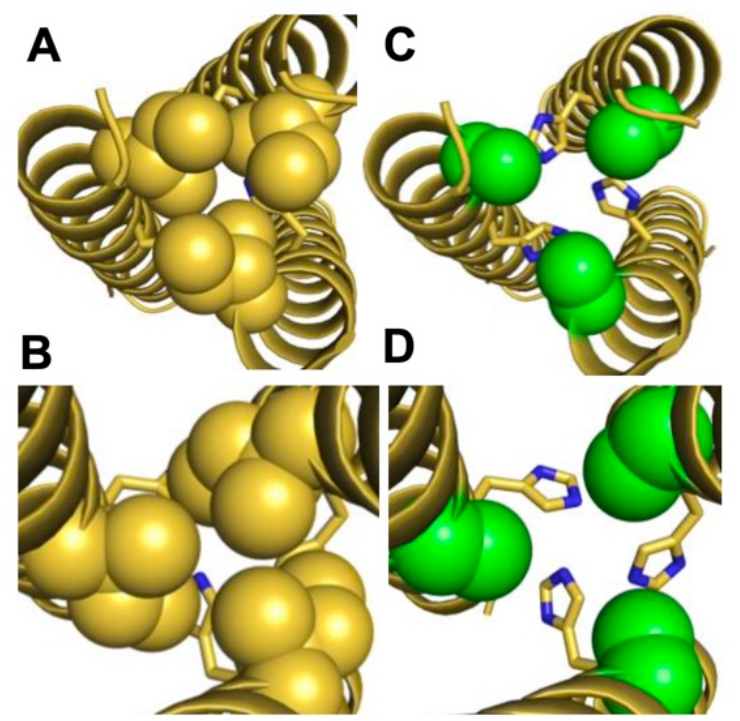

Figure 3. Packing of the $d$ site Ile (yellow spheres) immediately above (A) and below (B) the His site of Cu-3SCC. Ile to Ala (green spheres) substitution of the corresponding sites to opens up space at the outer sphere (C, D).

Table 3. Parameters from UV-vis kinetics.

\begin{tabular}{ccccc}
\hline Sample & $\boldsymbol{\varepsilon}\left(\mathbf{M}^{-1} \mathbf{c m}^{-1}\right)\left(\boldsymbol{\lambda}_{\max }\right)$ & Initial rate $\left(\mathbf{s}^{-\mathbf{1}}\right)$ & $\boldsymbol{\varepsilon}\left(\mathbf{M}^{-\mathbf{1}} \mathbf{c m}^{-\mathbf{1}}\right)\left(\boldsymbol{\lambda}_{\max }\right)$ & Initial rate $\left(\mathbf{s}^{-\mathbf{1}}\right)$ \\
\hline I5A-3SCC & $4.3 \times 10^{2}(365)$ & $8.9 \times 10^{-6}$ & $1.8 \times 10^{3}(346)$ & $4.6 \times 10^{-4}$ \\
I12A-3SCC & $1.3 \times 10^{2}(374)$ & $3.0 \times 10^{-5}$ & $1.9 \times 10^{3}(335)$ & $4.7 \times 10^{-4}$ \\
I5AI12A-3SCC & $2.4 \times 10^{2}(365)$ & $6.4 \times 10^{-6}$ & $2.1 \times 10^{3}(346)$ & $4.0 \times 10^{-4}$ \\
\hline
\end{tabular}

access. To probe how altering outer sphere sterics around $\mathrm{Cu}$ changes the physical and catalytic properties of the $\mathrm{ArCuPs}$, Ile residues at both the $\boldsymbol{d}$ sites above and below the $\mathrm{Cu}(\mathrm{His})_{3}$ site are replaced with Ala. The smaller $-\mathrm{CH}_{3}$ side chain of Ala is expected to provide a more facile access of substrates into the active site and change the polarity of the peptide interior. Gly was not chosen due to its flexibility which can break $2^{\circ}$ structures. Ala on the contrary, is a helix inducer. PyMol models of Ala mutants based on the x-ray structure of 3SCC indeed show that space is created in both I5A-3SCC (Fig. 3C) and I12A-3SCC (Fig. 3D) mutants. It is also intriguing that more space is created towards the C-termini, i.e. via the I12A mutation than the corresponding $\mathrm{N}$-termini side, as internal packing is controlled according to the helical twist within the core. The double mutant I5AI12A-3SCC is also prepared and tested.

ii. Rates of Cu-oxygen species formation: The formation of $\mathrm{Cu}-$ oxygen species was monitored by UV-vis under anaerobic conditions. Previously, we that shown that $\mathrm{Cu}^{\mathrm{II}}-3 \mathrm{SCC}$ reacts with $\mathrm{H}_{2} \mathrm{O}_{2}$ to form $\mathrm{Cu}$-hydroperoxo species with a rate of $1.4 \mathrm{x}$ $10^{-6} \mathrm{~s}^{-1}$, which was accelerated by $\sim 100$-fold in $\mathrm{Cu}^{\mathrm{I}}-3 \mathrm{SCC} .^{[7]}$ We have also shown that the differences in the spectral features with oxidized vs reduced forms of the peptide and $\mathrm{H}_{2} \mathrm{O}_{2}$ is attributed to differences in the His oxidation, which was observed with $\mathrm{Cu}^{\mathrm{I}}-3 \mathrm{SCC}$ and not with $\mathrm{Cu}^{\mathrm{II}}-3 \mathrm{SCC}$. With both $\mathrm{Cu}^{\mathrm{II}}$ and $\mathrm{Cu}^{\mathrm{I}}$ forms of the variants, slight differences in $\lambda_{\max }$ of the $\mathrm{Cu}-\mathrm{OOH}$ species are present (Fig. 4) compared to that of 3SCC (Table 3), indicating differences in the electronic environment around the active site. In $\mathrm{Cu}^{\mathrm{II}}$-form, the I5A3SCC and I5AI12A-3SCC have a similar $\lambda_{\max }$ of $365 \mathrm{~nm}$ (Fig. $4 \mathrm{~A}, \mathrm{C}$ ) and rates of 8.9-6.4 x 10-6 $\mathrm{s}^{-1}$ (Table 3; Fig. S8). 

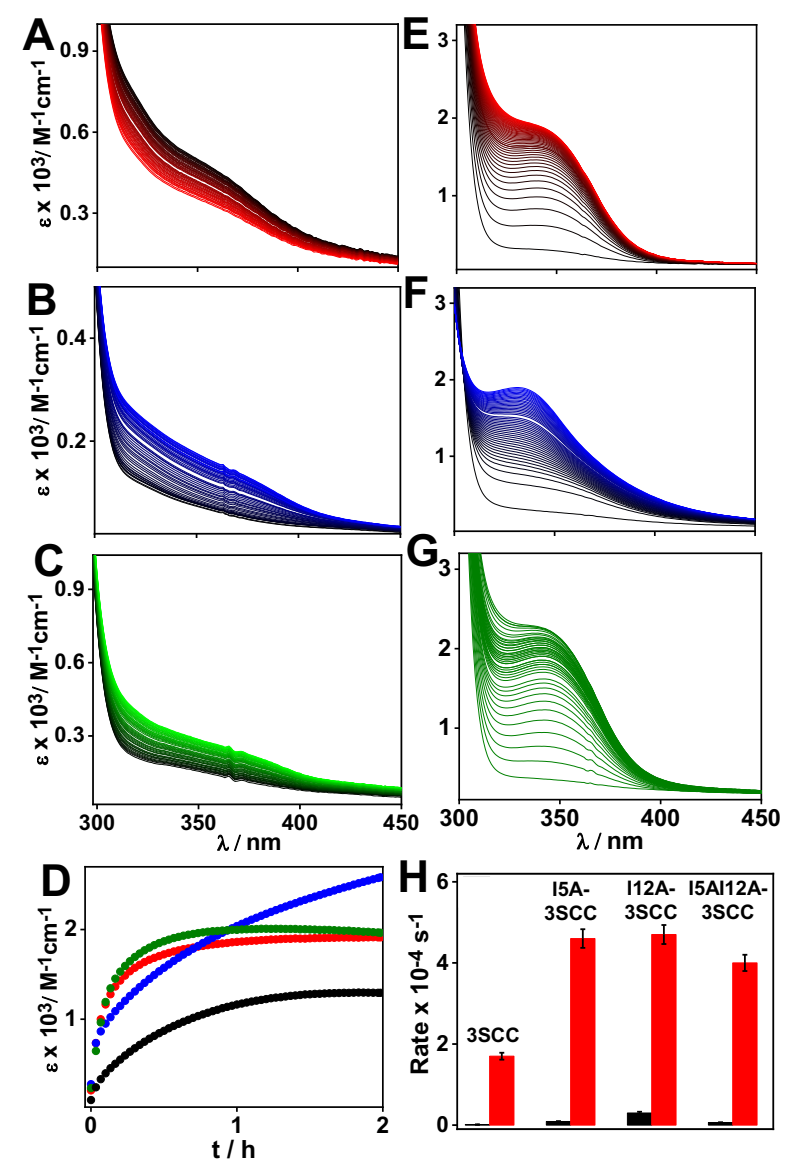

Figure 4. $\mathrm{UV}$-vis kinetics of $\mathrm{H}_{2} \mathrm{O}_{2}$ reaction with $\mathrm{Cu}^{\mathrm{II}} / \mathrm{Cu}^{\mathrm{I}}$ bound peptides I5A-3SCC (A/E), I12A-3SCC (B/F), and I5AI12A$3 \mathrm{SCC}(\mathrm{C} / \mathrm{G})$. Shown are the time dependent spectra after addition of $12.5 \mathrm{mM} \mathrm{H}_{2} \mathrm{O}_{2}$ to $0.125 \mathrm{mM}$ peptides in $\mathrm{N}_{2}$-saturated $10 \mathrm{mM}$ MES buffer at $\mathrm{pH}$ 6.5. (D) Time traces of the $\mathrm{Cu}^{\mathrm{I}}-\mathrm{ArCuPs}$ at respective $\lambda_{\max }$ (black $=3 \mathrm{SCC}$, red $=\mathrm{I} 5 \mathrm{~A}-3 \mathrm{SCC}$, blue $=\mathrm{I} 12 \mathrm{~A}$ $3 \mathrm{SCC}$, olive $=$ I5AI12A-3SCC). E) Initial rates of formation of $\mathrm{Cu}-\mathrm{OOH}$ species in the $\mathrm{Cu}^{\mathrm{II}}$ (black) and $\mathrm{Cu}^{\mathrm{I}}$ forms (red).

In contrast, the $\mathrm{Cu}-\mathrm{OOH}$ species in $\mathrm{I} 12 \mathrm{~A}-3 \mathrm{SCC}$ has a $\lambda_{\max }$ of $374 \mathrm{~nm}$ (Fig. 4B) and rate of $3 \times 10^{-5} \mathrm{~s}^{-1}$, which is approximately an order of magnitude higher than the other variants and the parent $3 \mathrm{SCC}$. In the $\mathrm{Cu}^{\mathrm{I}}$-form, the peaks blue shifted to $346 \mathrm{~nm}$ for I5A-3SCC (Fig. 4E) and I5AI12A-3SCC (Fig. 4G), and to $335 \mathrm{~nm}$ for I12A-3SCC (Fig. 4F). The rates of formation of $\mathrm{Cu}-\mathrm{OOH}$ species are accelerated to $\sim 10^{-4} \mathrm{~s}^{-1}$ with $\mathrm{Cu}^{\mathrm{I}}$-forms (Fig. $4 \mathrm{D}, \mathrm{H}$; Table 3 ). The higher rates with $\mathrm{Cu}^{\mathrm{I}}$-peptides are owing to the more reactive nature of $\mathrm{Cu}^{\mathrm{I}} / \mathrm{H}_{2} \mathrm{O}_{2}$ than $\mathrm{Cu}^{\mathrm{II}} / \mathrm{H}_{2} \mathrm{O}_{2}$, a conclusion which is consistent with what is observed in LPMO as well. ${ }^{[3,5 b, 15]}$ The rate enhancement in the variants compared to the parent $3 \mathrm{SCC}$ is indicative of a facilitated access of $\mathrm{H}_{2} \mathrm{O}_{2}$ to the $\mathrm{Cu}$ site of the variants. These data also hint reactivity differences in the mutants, where the I12A-3SCC variant clearly displaying differences in the nature of $\mathrm{Cu}$-oxygen species and the rate of its formation compared to the other two variants, which reflect the differences in substrate oxidation ability of this variant compared to others (vide infra).

iii. Differences in oxidative reactivity: Among all the $\mathrm{ArCuPs}$ investigated here, the highest $k_{c a t}$ and TON was obtained with
I12A-3SCC for all the substrates (Fig. S9, Table 2), while the WT $3 \mathrm{SCC}$ had the lowest $k_{\text {cat }}$. In general, $\mathrm{K}_{\mathrm{M}}$ is lower in I12A3SCC among the ArCuPs. Substrates $\mathbf{2}$ and $\mathbf{5}$ have lower $\mathrm{K}_{\mathrm{M}}$ than others. The catalytic proficiency is the highest for I12A3SCC irrespective of the substrate (Fig. 5, Table 2). Another obvious trend is that the I5A-3SCC and I5AI12A-3SCC have comparable catalytic proficiency. This observation is intriguing, since we expected that opening up space both above and below the $\mathrm{Cu}$ site in I5AI12A-3SCC would allow better access of substrates than either I15A-3SCC or I12A-3SCC.

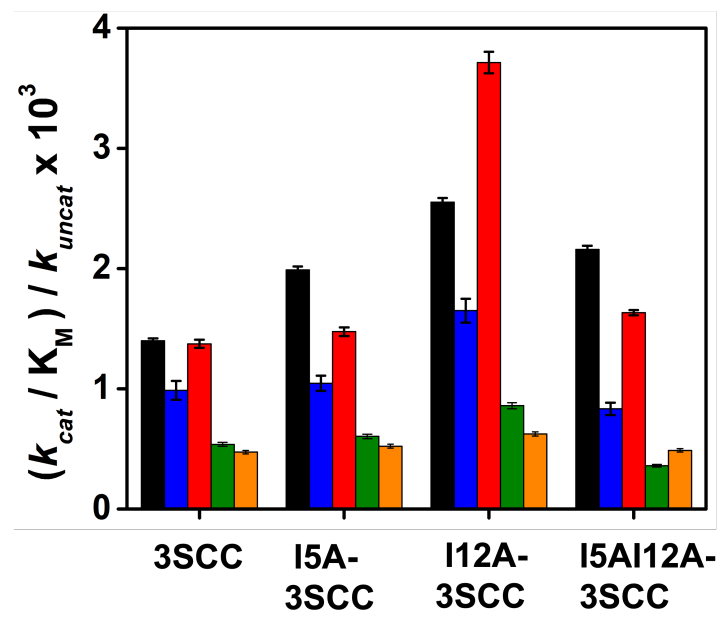

Figure 5. Electrocatalytic proficiency of the $\mathrm{ArCuPs}$ at $\mathrm{pH}$ 6.5. $k_{\text {cat }}$ and $k_{\text {uncat }}$ were obtained from the catalyzed and uncatalyzed reactions with the $\mathrm{ArCuPs}$ and the 3SCC-His mutant, respectively. $\mathrm{K}_{\mathrm{M}}$ is obtained from data in Fig. S1-5 at different concentrations of substrates. 1 (black), 2 (blue), 3 (red), 4 (olive), and 5 (orange).

However, this is not observed. This trend is consistent nonetheless, with the fact that similar spectral features and rates of formation of the $\mathrm{Cu}$-oxygen species in I5A-3SCC and I5AI12A-3SCC (Fig. 4, Table 3). The favorable reactivity for the I12A-3SCC mutant is likely attributable to the more space created below the $\mathrm{Cu}$ site allowing preferential access of $\mathrm{H}_{2} \mathrm{O}_{2}$ and substrates.

iv. Modulating outer sphere hydrophobicity tunes $E^{0}$ : We investigated how changes in the hydrophobicity due to outer sphere mutations alters the redox properties of the ArCuPs. Cyclic voltammograms for all the variants indicate the quasireversible nature of the redox process from well-defined protein films on the electrode (Fig. 6). The highest redox reversibility is observed for I5AI12A-3SCC (Fig. 6 olive) with a $\Delta \mathrm{E}_{\mathrm{p}}=4 \mathrm{mV}$ (Table 4) followed by I12A-3SCC (Fig. 6 blue). The I5A-3SCC (Fig. 6 red) with a $\Delta \mathrm{E}_{\mathrm{p}}$ of $80 \mathrm{mV}$ is the least reversible system. Both the cathodic and anodic peaks have large full width at half height $\left(\Delta \mathrm{E}_{1 / 2 \mathrm{c}}, \Delta \mathrm{E}_{1 / 2 \mathrm{a}}\right)$ which deviates from the theoretical value of $91 \mathrm{mV}$ for an ideal and reversible $1 \mathrm{e}^{-}$redox process, suggesting that dispersion and electrostatic effects influence the redox process. ${ }^{[16]}$ The peak currents show a linear dependence with scan rate, indicating a surface controlled redox process (Fig. S10). The positive $\mathrm{E}^{0}$ for all the mutants signify that the reduced forms of $\mathrm{ArCuPs}$ are more stable than the oxidized forms. The highest $\mathrm{E}^{0}$ is observed for the parent $3 \mathrm{SCC}$ peptide $(0.256 \mathrm{~V})$ followed by I5A- 


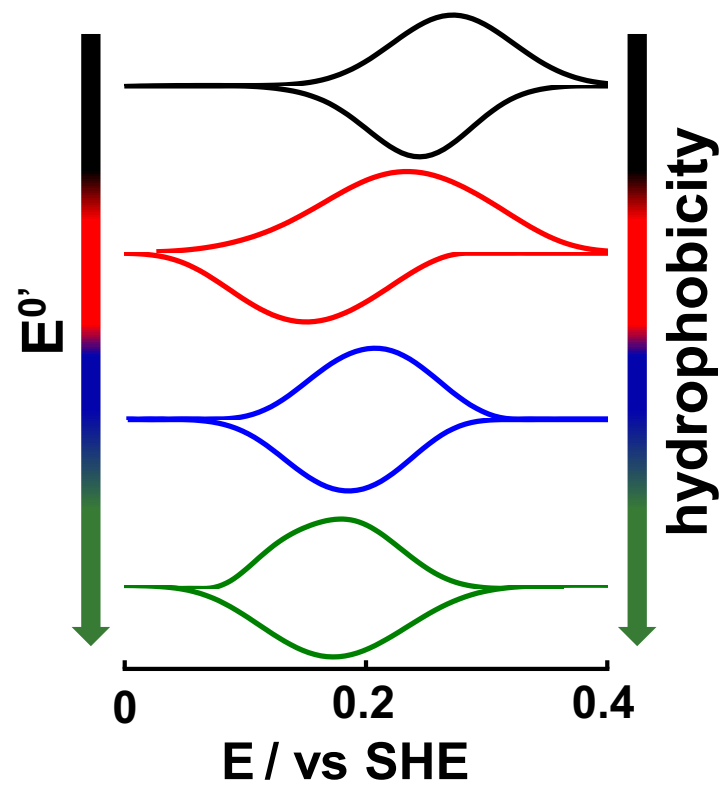

Figure 6. CVs of $3 \mathrm{SCC}$ (black), I5A-3SCC (red), I12A-3SCC (blue), and I5AI12A-3SCC (olive) at $50 \mathrm{mVs}^{-1}$ in $\mathrm{N}_{2}$ saturated $80 \mathrm{mM}$ mixed buffer at $\mathrm{pH}$ 6.5. The peptide samples were dropped on PGE and dried under $\mathrm{N}_{2}$ prior to data collection.

3SCC/I12A-3SCC (0.192 V and 0.198 V). The double mutant I5AI12A-3SCC has the lowest $\mathrm{E}^{0}$ of $0.178 \mathrm{~V}$. With a decrease in hydrophobicity around the active site, the $\mathrm{E}^{0} \mathrm{~s}$ shifted cathodically, implying that as the polarity around $\mathrm{Cu}$ is increased, $\mathrm{Cu}^{\mathrm{II}}$ state becomes more stable than $\mathrm{Cu}^{\mathrm{I}}$. In T1 ET protein azurin, modification of hydrophobicity and $\mathrm{H}$-bonding network around $\mathrm{Cu}$ ligands have led to the tuning of $\mathrm{E}^{0}$ by $\sim 700 \mathrm{mV} .{ }^{[17]}$ Unlike the $\mathrm{T} 1 \mathrm{Cu}$ proteins that span a wide potential range, the $\mathrm{E}^{0}$ of $\mathrm{T} 2 \mathrm{Cu}$ sites is regulated in a narrow window. ${ }^{[1 \mathrm{a}, 18]}$ In this context, tuning $\mathrm{E}^{0}$ of the $\mathrm{T} 2$ site of the ArCuPs by $\sim 80 \mathrm{mV}$ via modulating outer sphere steric is noteworthy. characteristics of $\alpha$-helix in the apo form except I5A12A, which is only weakly helical. In the $\mathrm{Cu}$-bound form, all constructs become more helical. Both apo (Fig. S12) and Cu3SCC undergo a transition from folded to unfolded state with a $t_{\mathrm{m}}$ of $\sim 65^{\circ} \mathrm{C}$ (Fig. 7 black, Table S1). Altering the $\boldsymbol{d}$ site above the His resulted in decreased stability of I5A-3SCC (Fig. S12) by $12{ }^{\circ} \mathrm{C}$ in the apo form compared to the parent construct. This is not unexpected, as Ile to Ala mutation lowers the packing interactions. Here, $\mathrm{Cu}^{\mathrm{II}}$-binding has negligible effect in thermostability (Fig. 7 red). Surprisingly, mutation at the $\boldsymbol{d}$ site

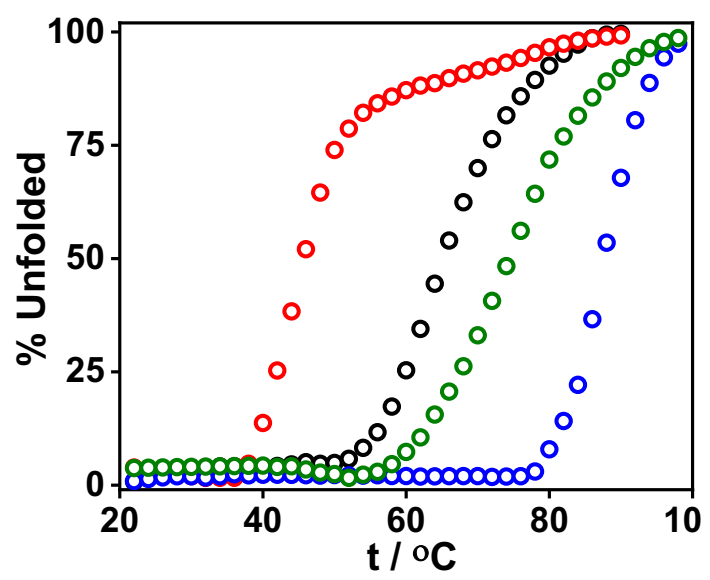

Figure 7. Thermal melting profiles of the ArCuPs (black = $3 \mathrm{SCC}$, red $=\mathrm{I} 5 \mathrm{~A}-3 \mathrm{SCC}$, blue $=\mathrm{I} 12 \mathrm{~A}-3 \mathrm{SCC}$, olive $=$ I5AI12A-3SCC) in their $\mathrm{Cu}^{\mathrm{II}}$-bound forms monitored at 222 $\mathrm{nm}$. All experiments were performed with $10 \mu \mathrm{M}$ trimers in $3 \mathrm{mM}$ phosphate buffer at $\mathrm{pH} 6.5$.

below the His led to an increased stability of I12A-3SCC mutant with $\mathrm{t}_{\mathrm{m}}$ increasing by $5^{\circ} \mathrm{C}$ in the apo form and by $22^{\circ} \mathrm{C}$ for the $\mathrm{Cu}$ bound peptide (Fig. 7 blue) compared to the $3 \mathrm{SCC}$ construct. The thermal melt for apo I5AI12A mutant does not show any obvious folding-unfolding transition (Fig. S12), which is consistent with the $\mathrm{CD}$ profile. $\mathrm{Cu}^{\mathrm{II}}-\mathrm{I} 5 \mathrm{AI} 12 \mathrm{~A}-3 \mathrm{SCC}$ behaves well folded and is quite stable with $\mathrm{t}_{\mathrm{m}} \sim 76{ }^{\circ} \mathrm{C}$ (Fig. 7 green). The highest $t_{m}$ of I12A-3SCC is unexpected as lost Van

Table 4. Redox properties of the ArCuPs at $\mathrm{pH} 6.5$.

\begin{tabular}{ccccccccc}
\hline Sample & $\mathbf{E}_{\mathbf{p c}} / \mathbf{m V}$ & $\mathbf{E}_{\mathbf{p a}} / \mathbf{m V}$ & $\mathbf{E}^{\mathbf{0}^{\prime}} / \mathbf{m V}$ & $\boldsymbol{\Delta} \mathbf{E}_{\mathbf{p}} / \mathbf{m V}$ & $\mathbf{\Delta} \mathbf{E}_{\mathbf{1 / 2 \mathbf { c }}} / \mathbf{m V}$ & $\mathbf{\Delta} \mathbf{E}_{\mathbf{1 / 2}} / \mathbf{m V}$ & $\mathbf{I}_{\mathbf{c}} / \boldsymbol{\mu A}$ & $\mathbf{I}_{\mathbf{a}} / \boldsymbol{\mu A}$ \\
\hline 3SCC & $239( \pm 6)$ & $273( \pm 5)$ & 256 & 34 & 92 & 132 & $-7.1( \pm 0.1)$ & $6.2( \pm 0.1)$ \\
I5A-3SCC & $152( \pm 4)$ & $232( \pm 3)$ & 192 & 80 & 130 & 153 & $-5.9( \pm 0.1)$ & $5.5( \pm 0.1)$ \\
I12A-3SCC & $188( \pm 4)$ & $208( \pm 4)$ & 198 & 20 & 106 & 121 & $-7.0( \pm 0.2)$ & $6.3( \pm 0.1)$ \\
I5AI12A-3SCC & $176( \pm 1)$ & $180( \pm 2)$ & 178 & 4 & 140 & 173 & $-7.1( \pm 0.1)$ & $7.1( \pm 0.1)$ \\
\hline
\end{tabular}

Although WT 3SCC has the highest $\mathrm{E}^{0}$, a lack of space around $\mathrm{Cu}$ limits substrate access and thus its reactivity. When comparing the variants, I5A-3SCC and I12A-3SCC have similar $\mathrm{E}^{0}$, higher than the double mutant. Yet, the catalytic proficiency of I5AI12A-3SCC is comparable to I5A-3SCC. However, despite having a similar $\mathrm{E}^{0} \mathrm{~s}$, the higher catalytic proficiency of I12A-3SCC than I5A-3SCC cannot be explained solely based on $\mathrm{E}^{0}$.

3. I12A-3SCC is the most stable construct: Unexpected trend. To probe how removal of Van der Waals interactions alters the folding and stability of the ArCuPs, CD spectroscopy was used (Fig. S11). In general, all the variants show der Waals packing by Ile to Ala mutation should destabilize the construct relative to the parent 3SCC peptide. It appears that while the Ile/Ile repeat at $\boldsymbol{a} / \boldsymbol{d}$ site is necessary to produce the trimers, the knob-into-holes packing ${ }^{[19]}$ of Ile residues at the $\boldsymbol{d}$ site does not produce the most stable assembly. Rather there is a trade-off between producing a specific oligomeric state vs peptide stability. Ile to Ala replacement likely relieves the unfavorable packing effect of $\boldsymbol{d}$ layer Ile residues. $\mathrm{Cu}$ binding further stabilizes the I12A-3SCC leading to a $\sim 19{ }^{\circ} \mathrm{C}$ increase in $t_{m}$ than the apo peptide. 


\section{SUMMARY AND CONCLUSIONS}

In this work, we have demonstrated the oxidation and peroxygenation as novel functional repertoire supported by de novo designed metalloproteins in regards to activation of $\mathrm{C}-\mathrm{H}$ bonds. The application of protein electrocatalysis is unprecedented in assessing the functional characteristics of ArMs. The outer sphere interactions of the ArCuPs were systematically modulated by opening space above and below the $\mathrm{Cu}(\mathrm{His})_{3}$ site that improved the rates of $\mathrm{Cu}$-oxygen species formation with $\mathrm{H}_{2} \mathrm{O}_{2}$ by providing a facile access of the oxidant. A larger space is selectively created towards the $\mathrm{C}$ termini, below the active site than the $\mathrm{N}$-termini, governed by the local packing effects controlled by the helical twist. The reactive intermediates, electrochemically generated cathodic to the redox peak of $\mathrm{Cu}^{\mathrm{II}}$-peptides abstract $\mathrm{H}$ atom from $\mathrm{C}-\mathrm{H}$ bonds of substrates. Under reducing conditions, the formation of $\mathrm{Cu}-\mathrm{OOH}$ species is significantly enhanced. This resonates with LPMO, in that the reductive priming is a critical step in generating reactive species that subsequently facilitates catalysis. A systematic decrease in hydrophobicity introduced by Ile to Ala mutations led to a cathodic shift of $\mathrm{E}^{0}$ as the increased polarity around the $\mathrm{Cu}$ site (water access) stabilizes the $\mathrm{Cu}^{\mathrm{II}}$ state over $\mathrm{Cu}^{\mathrm{I}}$. Here, altering the hydrophobicity $\sim 6 \AA$ away from the $\mathrm{T} 2 \mathrm{Cu}$ site tunes the $\mathrm{E}^{0}$ by $\sim 80 \mathrm{mV}$. Despite having highest $\mathrm{E}^{0}, 3 \mathrm{SCC}$ has the lowest activity and is due to the presence of large hydrophobic Ile residues above and below the active site, which hinders substrate access.

We expected I5AI12A-3SCC to be the most active variant as it would allow the most facile access of substrates. Surprisingly, the activity of this mutant is less than I12A3SCC, but comparable to I5A-3SCC. This has bearing to the fact the spectroscopic signatures and the rates of formation of $\mathrm{Cu}$-oxygen species in I5A-3SCC and I5AI12A-3SCC are comparable, implying that similar intermediates are generated in these two variants. In contrast, the spectroscopic features and the rate of formation of the $\mathrm{Cu}$-oxygen species is faster in I12A$3 \mathrm{SCC}$ even in the $\mathrm{Cu}^{\mathrm{II}}$-form, suggesting that this mutant is inherently more reactive. While the rates become comparable in all variants in the $\mathrm{Cu}^{\mathrm{I}}$-form, the spectroscopic features of I5A-3SCC and I15AI12A-3SCC remain similar to each other but distinct from I12A-3SCC. The thermal stability studies show that the I12A-3SCC is the most thermostable among all the studied peptides. This is unexpected as the mutation of Ile to Ala is expected to lower Van der Waals packing and thus destabilize the structure. We attribute to higher catalytic proficiency of I12A-3SCC to the highest stability of this variant along with the unique nature of $\mathrm{Cu}$-oxygen species generated in this variant. The I5A-3SCC is the least stable but the activity is comparable to I5AI12A-3SCC. While I5AI12A$3 \mathrm{SCC}$ has a higher stability than I5A-3SCC, the $\mathrm{E}^{0}$ ' of the former is lower than the latter. Clearly, when assessing the activity trends of the ArCuPs, one must be cognizant about a combined view of stability, $\mathrm{E}^{0}$, and the nature/rates of $\mathrm{Cu}-$ $\mathrm{OOH}$ intermediates, in addition to substrate accessibility.

A current limitation is the high $\mathrm{K}_{\mathrm{M}}$ for the substrates tested. One approach to lower $\mathrm{K}_{\mathrm{M}}$ and thus increase catalytic proficiency is to introduce aromatic residues near the $\mathrm{Cu}$ site which should allow docking of aromatic substrates by $\pi-\pi$ stacking- an approach which will be explored in the future. Indeed, this strategy has been applied in dimeric LmrR based ArMs. ${ }^{[20]} \mathrm{A}$ second limitation is that the self-assembling nature of $\mathrm{ArCuPs}$ which precludes tuning the reactivity by selective introduction of acidic or basic residues near the $\mathrm{Cu}$ site. An Asp residue in the outer sphere has been shown to be a critical factor in the activity of LMPOs. ${ }^{[3 b]}$ This aspect will be addressed in future studies via single-chain $\mathrm{ArCuP}$ design. In any case, the prospects of this study can be used in de novo design of ArMs and pave the way for developing efficient catalysts for small molecule activation.

\section{EXPERIMENTAL SECTION}

Materials and methods. All chemicals and reagents were of analytical grade and used without further purification. All the glassware and plasticware were immersed in a $10 \mathrm{mM}$ ethylenediaminetetraacetic acid bath overnight, followed by soaking in $10 \%$ and $1 \%$ nitric acid baths, respectively. All buffer solutions were prepared in Milli-Q (Millipore) water and treated with Chelex 100 overnight to remove trace metals. Tris(hydroxymethyl) aminomethane (TRIS), 4-(2hydroxyethyl)-1-piperazineethanesulfonic acid (HEPES), 3morpholinopropane-1-sulfonic acid (MOPS), 2-(Nmorpholino) ethanesulfonic acid (MES), sodium acetate, $\mathrm{NaCl}$ and $\mathrm{HCl}$ were purchased from Fisher Scientific. The mixed buffers contained $20 \mathrm{mM}$ each of MES, sodium acetate, HEPES and TRIS. For electrochemistry experiments $0.1 \mathrm{M}$ $\mathrm{KCl}$ was added as supporting electrolyte to the mixed buffers. $\mathrm{CuCl}_{2}$ (Alfa Aesar), ascorbic acid (VWR), $\mathrm{NaOH}$ (VWR), and $\mathrm{H}_{2} \mathrm{O}_{2}$ (VWR) stock solutions were made in water. $\mathrm{PhCD}_{2} \mathrm{OH}$ used for isotope labeling experiment was purchased from Sigma-Aldrich.

Peptide synthesis and purification. Peptides were synthesized, purified to homogeneity, and their identities verified according to known procedures. ${ }^{10}$

UV-vis Spectroscopy. The UV-vis spectra were recorded on an Agilent 8454 or Cary 5000 spectrophotometer. All samples were prepared in $10 \mathrm{mM}$ MES buffer at $\mathrm{pH}$ 6.5. The kinetics experiments were performed with $0.125 \mathrm{mM} \mathrm{Cu}$-peptides after the addition of $12.5 \mathrm{mM} \mathrm{H}_{2} \mathrm{O}_{2}$ and the kinetics was monitored for $100 \mathrm{~min}$ with $60 \mathrm{~s}$ interval between scans. For reactions with the $\mathrm{Cu}(\mathrm{I})$ form, $125 \mathrm{mM}$ Asc was used before $\mathrm{H}_{2} \mathrm{O}_{2}$ addition. All components were degassed, and the kinetics was monitored anaerobically in a septa-capped cuvette (Starna Cells). The initial rates were calculated from the first 3 minutes of the kinetic run in each case.

Circular dichroism (CD) spectroscopy. The CD spectra were recorded using a JASCO J-1500 spectrometer. $10 \mu \mathrm{M}$ trimer peptide samples were prepared in $3 \mathrm{mM}$ Phosphate buffer $\mathrm{pH}$ 6.5. Thermal unfolding experiments were performed by monitoring the $C D$ signal at $222 \mathrm{~nm}$ in the temperature range of $20-100{ }^{\circ} \mathrm{C}$.

\section{Electrochemistry.}

$i$. Non-catalytic voltammetry: Non-catalytic CV experiments were performed using a Wave Driver 20 bio-potentiostat (Pine Instruments) with pyrolytic graphite electrode (PGE) as the working electrode, coiled platinum wire as the counter electrode, and $\mathrm{Ag} / \mathrm{AgCl}$ (in saturated $\mathrm{KCl}$ ) as the reference electrode. $10 \mu \mathrm{L}$ of $125 \mu \mathrm{M}$ ArCuPs were drop-cast on PGE followed by $6 \mu \mathrm{L}$ of $0.1 \mathrm{M}$ polymyxin $\mathrm{B}$ to facilitate 
electrostatic interaction with the electrode. The drop was dried under $\mathrm{N}_{2}$, and voltammograms were recorded in $\mathrm{N}_{2}$-saturated $80 \mathrm{mM}$ mixed buffer solutions with $100 \mathrm{mM} \mathrm{KCl}$ as a supporting electrolyte. The potential values were referenced against $\mathrm{Ag} / \mathrm{AgCl}$ and converted to SHE.

ii. Electrode preparation for catalytic assays: All electrocatalytic experiments were performed using composites on glassy carbon electrode according to literature procedure. ${ }^{[21]}$ Briefly, $0.2 \%$ SWNT was dispersed in $4: 1$ ratio of water: ethanol mixture followed by addition of $0.1 \%(\sim 17 \mu \mathrm{L})$ nafion/ethanol. The mixture was then sonicated for $1 \mathrm{~h}$ at $37^{\circ} \mathrm{C}$. To the suspension, aliquots of the hetero bifunctional pyrene linker, 1-pyrenebutyric acid N-hydroxy succinimide ester $(4 \mu \mathrm{L}$ of $4 \mathrm{mg} / \mathrm{mL}$ ) (PBSE) dissolved in DMF were added and the mixture was incubated for $1 \mathrm{~h}$ at RT. The final samples were prepared by mixing SWNT/PBSE composite and the $\mathrm{ArCuP}$ in 1:1 ratio and incubated for $12-16 \mathrm{~h}$ at $4^{\circ} \mathrm{C}$. On one end PBSE linker attaches to SWNT via $\pi$ - $\pi$ interactions of the pyrene group whereas the other end is involved in amide bond formation with the $\mathrm{ArCuP}$. Finally, $10 \mu \mathrm{L}$ of assay composite was drop cast on GCE and dried under a gentle stream of $\mathrm{N}_{2}$.

iii. Electrocatalysis. Voltammograms were recorded in $80 \mathrm{mM}$ mixed buffer at pH 6.5 with $100 \mathrm{mM} \mathrm{KCl} .12 .5 \mathrm{mM} \mathrm{H}_{2} \mathrm{O}_{2}$ (final concentration) and $125 \mathrm{mM}$ substrates (final concentration) were added to the electrochemical cell and the mixture was made homogenous by adding $5 \mu \mathrm{L}$ of DMSO. The buffer was then saturated with $\mathrm{N}_{2}$ and LSVs were recorded. For CPE and chronoamperometry experiments, a potential of $-950 \mathrm{mV}$ vs $\mathrm{Ag} / \mathrm{AgCl}$ was applied. After electrolysis, the products were extracted using DCM in a separating funnel and dried over anhydrous $\mathrm{Na}_{2} \mathrm{SO}_{4}$. The extracted samples was then filtered and injected into GC.

The electrochemical surface coverage of the ArCuPs was determined using eq. (i)

$$
i_{p}=\frac{n^{2} F^{2} A \Gamma v}{4 R T}
$$

where $i_{p}$ is the peak current, $n$ is the number of electrons, $A$ is the surface area of the electrode calculated according to a known procedure ${ }^{[21 b]}$ from the redox peak shown in Fig. S13, $\Gamma$ is the surface coverage, $v$ is the scan rate, and F, R, T represent standard symbols. $k_{\text {cat }}$ was determined from eq. (ii)

$$
\mathrm{k}_{\mathrm{cat}}=\frac{\mathrm{j}_{\mathrm{cat}}}{\mathrm{nF \Gamma}}
$$

where $j_{\text {cat }}$ is the catalytic current density and $n$ is the number of electrons ( $\mathrm{n}=2$ or 4 in this case). $k_{\text {uncat }}$ for the uncatalyzed reaction was obtained similarly with the $3 \mathrm{SCC}$-His variant as a control, in the presence of $\mathrm{Cu}, \mathrm{H}_{2} \mathrm{O}_{2}$ and substrates.

Total charge $\mathrm{Q}$ passed during electrolysis was used to derive the maximum number of moles of the product from $\mathrm{Q} / \mathrm{nF}$. The maximum possible turnover $\left(\mathrm{TON}_{\max }\right.$ in Table 2) was calculated from the total charge consumed, where $n=2$ or 4 depending on the substrate. $\mathrm{K}_{\mathrm{M}}$ for each substrate was determined by chrono-coulometric experiments under varying substrate concentrations (Fig. S1-7).

Hammett analysis. A 1:1 mixture of benzyl alcohol and psubstituted benzyl alcohol at $125 \mathrm{mM}$ were added to an anaerobic solution reaction mixture containing $0.125 \mathrm{mM} \mathrm{Cu}^{\mathrm{I}}-$ 3SCC, $12.5 \mathrm{mM} \mathrm{H}_{2} \mathrm{O}_{2}$ at $\mathrm{pH}$ 6.5. The reaction was stirred overnight at $37{ }^{\circ} \mathrm{C}$ for $48 \mathrm{~h}$ and products were extracted in DCM. The log of the ratio of the area under the curve for the p-substituted benzyl alcohol to that of benzyl alcohol was plotted against the $\sigma_{p}$ values of the substituents to obtain the Hammett plot.

Gas chromatography. GC experiments were performed in a Shimadzu GC-2014 instrument using a capillary packed column equipped with an auto-sampler liquid injection port. 1 $\mu \mathrm{L}$ of samples were injected and spectra were recorded. The calibration of GC was performed with the respective standard samples to produce calibration curves and quantify products.

\section{ASSOCIATED CONTENT}

\section{Supporting Information}

The Supporting Information is available free of charge. Detailed electrocatalysis data for all mutants and substrates, $\mathrm{pH}$-dependence, kinetic traces of $\mathrm{Cu}^{\mathrm{II}}$-peptides, kcat plot, noncatalytic CVs, CD and thermal melts of the ArCuPs.

\section{AUTHOR INFORMATION}

\section{Corresponding Author: * saumenc@olemiss.edu}

Notes

The authors declare no competing financial interest.

\section{ACKNOWLEDGEMENTS}

S.C. thanks the University of Mississippi for support.

\section{REFERENCES}

[1] a) J. Liu, S. Chakraborty, P. Hosseinzadeh, Y. Yu, S. Tian, I. Petrik, A. Bhagi, Y. Lu, Chem. Rev. 2014, 114, 4366-4469; b) L. M. Mirica, X. Ottenwaelder, T. D. P. Stack, Chem. Rev. 2004, 104, 10131046; c) E. I. Solomon, D. E. Heppner, E. M. Johnston, J. W. Ginsbach, J. Cirera, M. Qayyum, M. T. Kieber-Emmons, C. H. Kjaergaard, R. G. Hadt, L. Tian, Chem. Rev. 2014, 114, 3659-3853. [2] G. Vaaje-Kolstad, B. Westereng, S. J. Horn, Z. Liu, H. Zhai, M. Sørlie, V. G. Eijsink, Science 2010, 330, 219-222.

[3] a) B. Bissaro, Å. K. Røhr, G. Müller, P. Chylenski, M. Skaugen, Z. Forsberg, S. J. Horn, G. Vaaje-Kolstad, V. G. Eijsink, Nat. Chem. Biol. 2017, 13, 1123; b) B. Bissaro, B. Streit, I. Isaksen, V. G. H. Eijsink, G. T. Beckham, J. L. DuBois, Å. K. Røhr, Proc. Natl. Acad. Sci., USA 2020, 117, 1504-1513.

[4] a) D. J. Spira-Solomon, E. I. Solomon, J. Am. Chem. Soc. 1987, 109, 6421-6432; b) D. E. Wilcox, A. G. Porras, Y. T. Hwang, K. Lerch, M. E. Winkler, E. I. Solomon, J. Am. Chem. Soc. 1985, 107, 4015-4027.

[5] a) L. Bertini, R. Breglia, M. Lambrughi, P. Fantucci, L. De Gioia, M. Borsari, M. Sola, C. A. Bortolotti, M. Bruschi, Inorg. Chem. 2018, 57, 86-97; b) P. Chylenski, B. Bissaro, M. Sørlie, Å. K. Røhr, A. Várnai, S. J. Horn, V. G. H. Eijsink, ACS Catal. 2019, 9, 4970-4991; c) S. Kim, J. W. Ginsbach, J. Y. Lee, R. L. Peterson, J. J. Liu, M. A. Siegler, A. A. Sarjeant, E. I. Solomon, K. D. Karlin, J. Am. Chem. Soc. 2015, 137, 2867-2874; d) S. Kim, C. Saracini, M. A. Siegler, N. Drichko, K. D. Karlin, Inorg. Chem. 2012, 51, 12603-12605; e) D. Maiti, A. A. Narducci Sarjeant, K. D. Karlin, Inorg. Chem. 2008, 47, 8736-8747; f) R. L. Peterson, R. A. Himes, H. Kotani, T. Suenobu, L. Tian, M. A. Siegler, E. I. Solomon, S. Fukuzumi, K. D. Karlin, J. Am. Chem. Soc. 2011, 133, 1702-1705; g) A. Kunishita, M. Kubo, H. Sugimoto, T. Ogura, K. Sato, T. Takui, S. Itoh, J. Am. Chem. Soc. 2009, 131, 2788-2789; h) S. Paria, T. Ohta, Y. Morimoto, T. Ogura, H. Sugimoto, N. Fujieda, K. Goto, K. Asano, T. Suzuki, S. Itoh, J. Am. Chem. Soc. 2015, 137, 10870-10873; i) S.-i. Yamazaki, S. Itoh, J. Am. Chem. Soc. 2003, 125, 13034-13035; j) C. H. Kjaergaard, M. F. Qayyum, S. D. Wong, F. Xu, G. R. Hemsworth, D. J. Walton, N. A. Young, G. J. Davies, P. H. Walton, K. S. Johansen, K. O. Hodgson, B. Hedman, E. I. Solomon, Proc. Natl. Acad. Sci., USA 2014, 111, 8797. 
[6] a) H. J. Davis, T. R. Ward, ACS Cent. Sci. 2019, 5, 1120-1136; b) F. Schwizer, Y. Okamoto, T. Heinisch, Y. Gu, M. M. Pellizzoni, V. Lebrun, R. Reuter, V. Kohler, J. C. Lewis, T. R. Ward, Chem. Rev. 2018, 118, 142-231; c) M. Jeschek, R. Reuter, T. Heinisch, C. Trindler, J. Klehr, S. Panke, T. R. Ward, Nature 2016, 537, 661-665; d) U. Markel, D. F. Sauer, J. Schiffels, J. Okuda, U. Schwaneberg, Angew. Chem. Int. Ed. 2019, 58, 4454-4464.

[7] S. Mitra, D. Prakash, K. Rajabimoghadam, Z. Wawrzak, P. Prasad, T. Wu, S. K. Misra, J. S. Sharp, I. Garcia-Bosch, S. Chakraborty, ACS Catal. 2021, 11, 10267-10278.

[8] a) M. Faiella, C. Andreozzi, R. T. M. De Rosales, V. Pavone, O. Maglio, F. Nastri, W. F. DeGrado, A. Lombardi, Nat. Chem. Biol. 2009, 5, 882-884; b) E. Mathieu, A. E. Tolbert, K. J. Koebke, C. Tard, O. Iranzo, J. E. Penner-Hahn, C. Policar, V. Pecoraro, Chem. Eur. J. 2020, 26, 249-258; c) A. J. Reig, M. M. Pires, R. A. Snyder, Y. Wu, H. Jo, D. W. Kulp, S. E. Butch, J. R. Calhoun, T. Szyperski, E. I. Solomon, W. F. DeGrado, Nat. Chem. 2012, 4, 900-906; d) M. Tegoni, F. Yu, M. Bersellini, J. E. Penner-Hahn, V. L. Pecoraro, Proc. Natl. Acad. Sci., USA 2012, 109, 21234-21239; e) M. L. Zastrow, A. F. A. Peacock, J. A. Stuckey, V. L. Pecoraro, Nat. Chem. 2012, 4, 118-123.

[9] S. Malayam Parambath, A. E. Williams, L. A. Hunt, D. Selvan, N. I. Hammer, S. Chakraborty, ChemSusChem 2021, 14, 2237-2246.

[10] a) F. Yu, V. M. Cangelosi, M. L. Zastrow, M. Tegoni, J. S.

Plegaria, A. G. Tebo, C. S. Mocny, L. Ruckthong, H. Qayyum, V. L. Pecoraro, Chem. Rev. 2014, 114, 3495-3578; b) I. V. Korendovych, W. F. DeGrado, Q. Rev. Biophys. 2020, 53.

[11] a) J. L. Beesley, D. N. Woolfson, Curr. Opin. Biotechnol. 2019, $58,175-182$; b) D. N. Woolfson, J. Mol. Biol. 2021, 167160; c) J. M. Fletcher, A. L. Boyle, M. Bruning, G. J. Bartlett, T. L. Vincent, N. R. Zaccai, C. T. Armstrong, E. H. C. Bromley, P. J. Booth, R. L. Brady, A. R. Thomson, D. N. Woolfson, ACS Synth. Biol. 2012, 1, 240-250. [12] a) M. Mukherjee, A. Dey, ACS Cent. Sci. 2019, 5, 671-682; b) M. Mukherjee, A. Dey, Inorg. Chem. 2020, 59, 7415-7425.

[13] a) S. Studer, D. A. Hansen, Z. L. Pianowski, P. R. E. Mittl, A.

Debon, S. L. Guffy, B. S. Der, B. Kuhlman, D. Hilvert, Science 2018, 362, 1285-1288; b) D. Hilvert, Annu. Rev. Biochem. 2013, 82, 447-

470.

[14] M. M. Whittaker, J. W. Whittaker, Biochemistry 2001, 40, 71407148.

[15] B. Bissaro, Å. K. Røhr, M. Skaugen, Z. Forsberg, S. J. Horn, G. Vaaje-Kolstad, V. G. Eijsink, bioRxiv 2016, 097022.

[16] a) J. Hirst, Biochim. Biophys. Acta 2006, 1757, 225-239; b) A. P. Brown, F. C. Anson, Anal. Chem. 1977, 49, 1589-1595.

[17] N. M. Marshall, D. K. Garner, T. D. Wilson, Y.-G. Gao, H.

Robinson, M. J. Nilges, Y. Lu, Nature 2009, 462, 113-116.

[18] a) F. L. Aachmann, M. Sørlie, G. Skjåk-Bræk, V. G. Eijsink, G. Vaaje-Kolstad, Proc. Natl. Acad. Sci. 2012, 109, 18779-18784; b) S. Chauhan, P. Hosseinzadeh, Y. Lu, N. J. Blackburn, Biochemistry 2016, 55, 2008-2021; c) F. Jacobson, A. Pistorius, D. Farkas, W. De Grip, Ö. Hansson, L. Sjölin, R. Neutze, J. Biol. Chem. 2007, 282, 6347-6355; d) S. Suzuki, K. Yamaguchi, K. Kataoka, K. Kobayashi, S. Tagawa, T. Kohzuma, S. Shidara, H. Iwasaki, J. Biol. Inorg. Chem. 1997, 2, 265-274.

[19] a) J. Walshaw, D. N. Woolfson, Biochem. Soc. Trans. 2000, 28, A423-A423; b) C. I. Branden, J. Tooze, Introduction to protein structure, Garland Science, 2012.

[20] G. Roelfes, Acc. Chem. Res. 2019, 52, 545-556.

[21] a) S. Chakraborty, S. Babanova, R. C. Rocha, A. Desireddy, K. Artyushkova, A. E. Boncella, P. Atanassov, J. S. Martinez, J. Am

Chem. Soc. 2015, 137, 11678-11687; b) Z. Nazemi, P. Prasad, S.

Chakraborty, ChemElectroChem 2020, 7, 1029-1037. 